\title{
Family farming workers mental health in a microrregion in southern Brazil
}

\author{
Ângela Regina Poletto ${ }^{\mathrm{a}}$, Leila Amaral Gontijo \\ ${ }^{a}$ Federal Institute of Education, Science and Technology of Santa Catarina - IF-SC, Florianópolis - SC Brazil \\ ${ }^{\mathrm{b}}$ Federal University of Santa Catarina, Florianópolis - SC(Brazil
}

\begin{abstract}
This research aims at investigating family farming workers' of Ituporanga microregion mental health problems and sociodemographical feature and work process association. The sample corresponded to 447 family farming workers in Ituporanga, i. e., part of the overall population lives in the 1.578 rural properties of the city (IBGE, 2007). A questionnaire with socio-demographic and work process variables was used for data collection concerning mental health problems along with the Self Report Questionnaire (SRQ-20). Inference descriptive statistics with central trend measures and variability was used for data analysis. By means of binary logistic regression the probability of an event, i.e. the presence of mental health problems occur as a result of predicting variables. Level of significance 5\% was adopted in all statistical procedures. The investigation revealed the prevalence of $33,8 \%$ of mental health problems. It was observed that women prevailed with $39,7 \%$ ( $\mathrm{n}=91)$, in contrast with men with $26,1 \%(n=46)$, being such association statistically significant $\left(X^{2}=8,225, d f=1, p=0,004, p h i=-0,143\right)$. Socio-demographical and work process variables showed predictors of mental health problems, such as: (sex, age, use of agrochemicals, working hours outside and during harvest time, being family intoxication the most important. Mental health problems showed mostly associated to the use of agro-chemicals and farmers being intoxicated.
\end{abstract}

Keywords: agriculture; work process; socio-demographic variables.

\section{Introduction}

International literature has approached the significance of mental health problems associated to farmers' activities (Gregoire, 2002), like high stress levels (McGregor; Willock; Deary, 1995; Booth; Lloyd, 1999; Lobley et al., 2004), depression and anxiety (Eisner; Neal; Scaife, 1999) as well as increased cases of suicide (Malmberg; Hawton; Simkin, 1997; Conger, 1999; Booth et al., 2000; Page; Fragar, 2002).

For Fraser et al. (2005), research with farmer workers in Australia, Canada, Europe and the United States indicate that farmers and their families display stress factors related to their physical environment, farming family structure, economic problems and uncertainties associated with their agricultural property, all of which can be harmful to mental health.

* Corresponding authors. Emails: angelapoletto@ifsc.edu.br, leila@deps.ufsc.br
In Brazil, just a few studies approach mental health of agricultural workers and the majority refers to the population in general. Faria et al. (1999, 2000) found high prevalence of minor psychiatric morbidity in agricultural workers in Brazil; however, researchers highlight the complexity of occupational expositions studied.

Falk et al. (2003), in Venâncio Aires, Southern Brazil, verified high prevalence of mental health problems and suicides, being a consensus that the phenomenon predominates in the rural area. Suicide levels are alarming, which results in Venâncio Aires having one of the highest numbers of cases for every one hundred thousand inhabitants in the world.

This study is justified by the increased number of mental health problems in several parts of the world, including Brazil, and the complexity that family farming work involves. Upon these facts and studies showing that the working process can cause mental health problems, this study aims at investigating the prevalence of mental health problems and association of socio-demographic features and 
working processes of family agricultural workers in the microregion of Ituporanga.

\section{Method}

This transversal delineation research is an exploratory and descriptive field research. The study was undertaken in the microregion of Ituporanga, Southern region of Brazil, in the State of Santa Catarina. With a total area of $2713.2 \mathrm{~km}^{2}$, the microregion has predominantly small properties with diversified structures and farming production family structure. Total population of the microregion is 69.293 inhabitants, where 41,894 inhabitants are rural and 27.395 are urban population, with 9.224 rural establishments in 10 municipalities (IBGE, 2007).

Sample was selected in the municipality of Ituporanga, as it is one of the representative municipalities of family farming in the microregion. For sampling selection, simple random sampling calculus was used. Sample size was calculated based on Barbetta (2003) with a sample error of $4 \%(\mathrm{E} \circ=$ $0,04)$ and confidence interval for mean of $95 \%$. Research sample corresponded to 447 family farmer workers under activity in the municipality of Ituporanga, i.e., part of a total resident population of 1.578 rural properties in the municipality (IBGE, 2007).

Given the complexity involving family farming work, only farmers from owner families were selected and one person was interviewed from each property. Protocols referring to the research were sent to the Ethics in Human Beings Research Committee, at the Federal University of Santa Catarina. Interviewees were informed about the theme, objectives and ethical commitments of the research; the consent form was freely signed and clarified, a requisite for the interviews to take place.

For the survey of socio-demographic features, the following socio-demographic indicators were identified: sex, age (completed years), civil state, ethnicity, religion and education level. As to working process, the following indicators were identified: predominant crop, working hours, area of property, use of machinery and equipment, hiring of staff, use of veterinarian products as well as use of agro-chemicals and intoxications. A questionnaire with socio-demographic and working process variables was applied.

Mental health problems were measured by the Self Report Questionnaire (SRQ-20) where the test was positive with eight changed answers for women and six for men (Mari; Willians, 1986). The SRQ 20 allows tracing minor psychiatric disturbances for a significative sampling of the population. It was validated by international studies (Wilkinson, 1887) and, in Brazil, in users of primary attention (Mari; Willians, 1986; Mari et al., 1987). The SRQ 20 was used in Faria et al. (1999) study, with agricultural workers in Brazil, thus the translation of its field test was not needed for this study.

For the statistical analysis, a descriptive and inferential statistic was used. In order to describe data, central tendency measures (central and mode) and variability (standard deviation, variation, frequency and percentages) were used.

In order to answer the specific objective of the study, which was to identify factors that contribute towards mental health problems of farming workers, binary logistic regression was used. As adequation test of regression model, Omnibus and Hosmer and Lemeshow tests were used. Regression method used was Enter, as steps were not done in the model, but rather, tests in three different models. Tested models had as dependant variable the mental health problem. This variable was measured by SRQ 20 (HARDING et al.,1980), where groups (with problem/without problem) were identified from a suggested and validated cutting point by the author of the scale with the same population, which is eight points for women and six for men.

In the first model, predictive capacity of sociodemographic variables were tested; in the second model, predictive capacity of variables related to the working process; and finally, a third binary logistic regression was done using dependent variables those presenting significative predictive capacity in the earlier models.

In order to test the other specific objectives, unvaried hypothesis tests were used. Verification of association amongst category variables was done using a chi-square test. In order to compare continuous variables means amongst groups with two categories, a t test for independent samples. For the comparison of working hours outside and during harvest time, a paired $t$ test was used. The significance value adopted was 0,05 .

\section{Results}

3.1 Sociodemographic and work process in the properties characterization 
In the studied sample, $43,5 \%(n=176)$ were men and $56,5 \%(\mathrm{n}=229)$ women. Mean age of farmers was $48,9(\mathrm{DP}=14.4)$ for women, with ages ranging from 18 to 85 . When comparing the mean age of men and women, it was noticed that men present a significantly higher age mean than women $\left(\mathrm{t}_{(403)}=\right.$ 3,376; $<<0,001$ ).

Regarding family origins, German stands out, with $64 \%$ of workers. Predominant religion is Catholic with $74,6 \%$, following by Lutheran with $24 \%$ and other religions with $1,4 \%$. When families were characterised as to number of children, the mean was $3.16(\mathrm{DP}=2,3)$. The reduced number of children helping with the work was also noticed, a mean of $0,82(\mathrm{DP}=1,0)$.

It was noticed when working process characteristics were analysed that family farmers have, in mean, properties with 17,3 ha $(\mathrm{DP}=15,7)$ and $44.9 \%$ of properties have between one to 10 ha and only $7.4 \%$ in the studied sample are over 40 ha.

Predominant crops in the properties are onion $50,1 \%(n=203)$ and tobacco 54,3\% $(n=220)$. Other significant crops were corn $56,8 \%(\mathrm{n}=230)$, beans $17,8 \% \quad(n=72)$ and horticulture $10,9 \% \quad(n=44)$. Animal production is also present in $25.2 \%(n=102)$, mainly cattle, swine and birds.

Workers make use of manual tools, when asked about use of machinery, $48,4 \%$ affirmed not using it. Larger properties have good level of mechanization in the region, especially onion producers.

Farmers are members of the owner family and when asked about hiring of staff, 20,2\% affirmed resorting to this practice. Hiring of complementary work force happens in properties with higher production activity, and for shorter periods of time. Farmers usually help neighbours in the activities, according to the needs of each property, especially in times of intense work (transplant and harvest).

During harvesting working hours are extensive, with a mean of 12,9 hours daily $(\mathrm{DP}=2,6)$. It was noticed that some farmers $(n=55 ; 13,6 \%)$ work over 16 hours, especially during the transplant period during winter/spring and during harvesting during spring/summer. It was also noticed that tobacco farmers, many times, work over 18 hours to take care of the greenhouses in the cure process. Outside harvesting, the average working hour lowers to 9,1 daily $(\mathrm{DP}=1,8)$. In order to compare the mean worked hours during harvesting and outside harvesting, the paired t test was used, and it was verified that the mean working hours during harvesting is significantly higher than the hours outside harvesting $\left(\mathrm{t}_{(404)}=34,691 ; \mathrm{p}<0,001\right)$.

Regarding the use of agrotoxin, 85,9\% $(n=348)$ of the famers referred to the regular use of agrochemicals. Periods of the year with highest intensity of use of pesticides are the months following transplant (winter/spring) until harvesting (spring/summer). Farmers use herbicides, fungicides and insecticides. Besides agro-chemicals 47,2\% $(\mathrm{n}=191)$ use veterinarian products for cattle farming. Intoxications were also noticed to be caused by agro-chemicals: $40,5 \%$ of workers affirmed having had intoxication problems in the family and $23,7 \%$ affirmed that they were intoxicated themselves.

When analysing intoxication in the properties, according to the predominant crop, i.e., in the main crops (onion and tobacco), it was verified that $50 \%$ of the farmers planting tobacco have already had intoxication in the family, as well as $36 \%$ of the farmers planting onions. Amongst farmers planting tobacco, 29,1\% affirmed having being intoxicated themselves by the use of agro-chemicals and $21,7 \%$ amongst farmers planting onions. Data show that intoxication by agro-chemicals in the family is lower amongst onion producers.

\subsection{Mental Health Problems}

Prevalence of mental health problems amongst farmers was $33,8 \%(n=137)$. Rate of mental health problems was standardized by age and sex. When gender prevalence was verified, it was noticed that women have a prevalence of $39,7 \%(n=91)$ and men $26,1 \% \quad(n=46)$. By associating mental health problems to sex, it was noticed that women present higher prevalence than men. This association is statistically significant $\left(\mathrm{X}^{2}=8,225 ; \mathrm{df}=1 ; \mathrm{p}=0,004\right.$; phi=-0,143).

Table 1 was prepared in order to analyse frequency and percentage of positive answers for each question from the SRQ-20 and it describes the main symptoms stated by the farmers.

Regarding questions from the SRQ-20, it was noticed that highest frequency of affirmative answers were: feeling nervous, tense or worried $(58,8 \%)$, daily work being affected $(54,6 \%)$, being easily frightened $(44,7 \%)$, sleeping badly $(41,7 \%)$, feeling unhappy lately $(40 \%)$, as per Table 1 . 
Table 1

Results Self Report Questionnaire

\begin{tabular}{|c|c|c|c|c|}
\hline \multirow{2}{*}{ Variables } & \multicolumn{2}{|c|}{ Occurrence of symptom \% (n) } & \multirow[b]{2}{*}{$\mathbf{X}^{2}$} & \multirow[b]{2}{*}{ P-value } \\
\hline & $\begin{array}{c}\text { All } \\
\text { respondents }\end{array}$ & $\begin{array}{l}\text { Mental Health } \\
\text { Problems }\end{array}$ & & \\
\hline 1. Do you often have headaches? & $36,3(147)$ & $57,1(84)$ & 56,041 & $<0,001$ \\
\hline 2. Is your appetite poor? & $15,3(62)$ & $64,5(40)$ & 30,801 & $<0,001$ \\
\hline 3. Do you sleep badly? & $41,5(168)$ & $58,3(98)$ & 77,023 & $<0,001$ \\
\hline 4. Are you easily frightened? & $44,4(180)$ & $51,7(93)$ & 46,064 & $<0,001$ \\
\hline 5. Do your hands shake? & $20,7(84)$ & $65,5(55)$ & 47,425 & $<0,001$ \\
\hline 6. Do you feel nervous, tense, or worried? & $58,8(238)$ & $51,2(122)$ & 78,367 & $<0,001$ \\
\hline 7. Is your digestion poor? & $23(93)$ & $67,3(63)$ & 62,032 & $<0,001$ \\
\hline 8. Do you have trouble thinking clearly? & $20,5(83)$ & $77,1(64)$ & 87,364 & $<0,001$ \\
\hline 9. Do you feel unhappy? & $39,8(161)$ & $68,9(111)$ & 147,224 & $<0,001$ \\
\hline 10. Do you cry more than usual? & $32,6(162)$ & $72(95)$ & 127,274 & $<0,001$ \\
\hline $\begin{array}{l}\text { 11. Do you find it difficult to enjoy your daily } \\
\text { activities? }\end{array}$ & $13,3(54)$ & $94,4(51)$ & 102,280 & $<0,001$ \\
\hline 12. Do you find it difficult to make decisions? & $21,5(87)$ & $49,4(43)$ & 12,043 & $<0,001$ \\
\hline 13. Is your daily work suffering? & $54,8(222)$ & $42,3(94)$ & 15,915 & $<0,001$ \\
\hline $\begin{array}{l}\text { 14. Are you unable to play a useful part in } \\
\text { life? }\end{array}$ & $10,1(41)$ & $78(32)$ & 39,853 & $<0,001$ \\
\hline 15. Have you lost interest in things? & $11,9(48)$ & $93,8(45)$ & 87,351 & $<0,001$ \\
\hline $\begin{array}{l}\text { 16. Do you feel that you are a worthless } \\
\text { person? }\end{array}$ & $7,2(29)$ & $96,6(28)$ & 54,903 & $<0,001$ \\
\hline $\begin{array}{l}\text { 17. Has the thought of ending your life been on } \\
\text { your mind? }\end{array}$ & $5,4(22)$ & $95,5(21)$ & 39,471 & $<0,001$ \\
\hline 18. Do you feel tired all the time? & $37,5(152)$ & $64,4(101)$ & 115,666 & $<0,001$ \\
\hline $\begin{array}{l}\text { 19. Do you have uncomfortable feelings in } \\
\text { your stomach? }\end{array}$ & $30,6(124)$ & $62,1(77)$ & 63,806 & $<0,001$ \\
\hline 20. Are you easily tired? & $38(154)$ & $63,6(98)$ & 98,641 & $<0,001$ \\
\hline
\end{tabular}

When analysing the results, it was noticed that questions 9, 10, 11, 15, 16 and 17 were first positively answered by the farmers that presented mental health problems. Therefore, these questions were the ones with higher chi square values, indicating that they are important symptoms of the disease.

\subsection{Association of mental health problems}

When analysing the prevalence of mental health problems associated to sociodemographic features, a higher prevalence was found amongst women; aged over 40; of mixed and others/does not know how to answer; married (34,3\%) and widow/separated $(33,3 \%)$; and belonging to the Catholic religion. Although these tendencies were observed, only sex difference was statistically significant.

Mental health problems were associated to features of family agricultural working process.
When associating mental health problem to agricultural production in the predominant crops, the noticed prevalence was $37,4 \%$ amongst onion producers and $36,8 \%$ for tobacco producers, with great similarity between them. The use of machinery and equipment in the property, an indicator of technological development, and hiring of staff were associated to less prevalence of mental health problems.

Prevalence of mental health problems in farmers that had intoxication in the family was $48,8 \%$, and without intoxication $23,7 \%$. It was noticed that frequency of answers of farmers with family intoxication was statistically higher $\left(X^{2}=27,530\right.$; $\mathrm{p}<0,000)$ than the mean of farmers without intoxication, as shown under Table 2. 
Table 2

Association by agro-chemicals intoxication, intoxicated farmers and mental health problems

\begin{tabular}{|c|c|c|c|c|c|c|}
\hline \multirow[t]{2}{*}{ Variables } & \multicolumn{2}{|c|}{ (n) } & \multicolumn{2}{|c|}{$\begin{array}{l}\text { Mental Health } \\
\text { Problem (\%) }\end{array}$} & \multirow[t]{2}{*}{$\mathbf{X 2}$} & \multirow[t]{2}{*}{ P-value } \\
\hline & Yes & No & Yes & No & & \\
\hline - $\quad$ Family intoxication & 79 & 57 & 48,8 & 23,7 & 27,530 & $<0,000$ \\
\hline - $\quad$ Farming intoxications & 42 & 95 & 44,8 & 30,4 & 6,758 & 0,009 \\
\hline
\end{tabular}

According to Table 2, it was observed that 44,8\% of intoxicated farmers presented mental health problems, while only $30.4 \%$ of farmers without intoxication. When comparing frequencies, it was noticed that intoxicated farmers had higher prevalence, but not statistically significant $\left(X^{2}=6\right.$, $758 ; \mathrm{p}<0,009)$.

It was noticed that women presented higher prevalence of mental health problems in relation to men, both with family intoxication and being intoxicated themselves. When comparing frequencies, it was noticed that intoxicated women presented higher occurrence of mental health problems than the ones not intoxicated $\left(X^{2}=17\right.$, $661 ; \mathrm{p}<0,000)$. Results showed that the regular use of agro-chemicals pesticides and intoxication are directly associated with mental health problems prevalence.

\subsubsection{Prevalence of mental health problems and association factors}

Through binary logistic regression, the probability of an event was analysed, in this case, a mental health problem occurring because of predictive variables. There are two groups of variables that influence the mental health of a worker (socio-demographic and working process characteristics). In order to test the predictive capacity of these groups on mental health problems, two logistic regressions were done, one for each group. After the procedure, variables with higher predictive capacity on the mental health of both groups were selected, which served as independent variables for the third model of regression undertaken.

The first regression model had as independents variables (predictive) socio-demographic characteristics (sex, age, civil state, educational level, religion and time of living in the area) and as dependent variable, the mental health problem indicator (yes or no).
Results of Omnibus tests indicated that the tested model was adequate $\left(\mathrm{X}^{2}=25,160 ; \mathrm{p}=0,003\right)$, suggesting that some variables could significantly

predict mental health problems. Both Hosmer and Lemeshow tests indicated that values predicted by the model did not significantly differentiated from the values observed $\left(\mathrm{X}^{2}=4,034 ; \mathrm{p}=0,854\right)$.

It was noticed that, amongst socio-demographic characteristics, the most important predictive variables were sex (male), age and time of living in the property. It was safe to say that regarding sex, men have half the chance of having a mental health problem. Regarding age, it was observed that higher the age, the greater the chances are of having mental health problems, but this tendency is less accentuated. Time of living in the area indicated that the longer the farmers lived in the property, the smaller was the chance of having a mental health problem.

The second regression model had as independent variables (predictive) working process characteristics (working hours during harvesting and outside harvesting, onion producers, tobacco producers, hiring of staff, use of machineries, use of agro-chemicals, family intoxications and intoxicated farmers), and as dependent variable, the mental health problem indicator (yes or no).

Results of Omnibus tests indicated that the model was adequate $\left(X^{2}=61,550 ; p=0,000\right)$, suggesting that some variables could significantly predict mental health problems. Both Hosmer and Lemeshow tests indicated that the model was adequate to the data, as predicted values did not significantly differentiate from observed values $\left(X^{2}=9,715 ; p=0,286\right)$.

Regarding the working process, it was noticed that variables of working hours during harvesting and outside harvesting, family intoxication, onion producers and use of agro-chemicals are predictive variables of mental health problems.

Regarding working hours, it was noticed that the higher the number of worked hours during harvesting, less are the chances of having mental health problems. The opposite is observed to numbers of working hours outside harvesting, as 
whoever works more hours outside harvesting has a greater chance of having mental health problems.

It was noticed that onion producers are more likely to have mental health problems than tobacco producers. When analysing the mental health problems of both onion and tobacco producers, prevalence was very similar. The use of agrochemicals has a direct relationship with the mental health problems and family intoxication is the highest predictor.

The third regression model had as independent variables (predictive) socio-demographic characteristics, of the working process, and as dependent variable, the mental health problem indicator (yes or no).

Omnibus test results indicated that the tested model was adequate $\left(\mathrm{X}^{2}=65,138 ; \mathrm{p}=0,000\right)$, suggesting that some variables could significantly predict mental health. Both Hosmer and Lemeshow tests indicated that the model was adequate to the data, as the predictive values did not differentiate from the observed values $\left(X^{2}=2,632 ; p=0,955\right)$.

Table 3

Results of binary logistic regression of socio-demographic characteristics and working process in predicting mental health problems

\begin{tabular}{|c|c|c|c|c|c|c|c|c|}
\hline \multirow[t]{2}{*}{ Variables } & \multirow[t]{2}{*}{$\mathbf{B}$} & \multirow[t]{2}{*}{ SE } & \multirow[t]{2}{*}{ Wald } & \multirow[t]{2}{*}{ DF } & \multirow[t]{2}{*}{ Sig } & \multirow[t]{2}{*}{$\operatorname{Exp}(B)$} & \multicolumn{2}{|c|}{ 95\% C.I. EXP(B) } \\
\hline & & & & & & & Low & Upper \\
\hline Sex (Male) &,- 624 & 246 & 6,417 & 1 & ,011 &, 536 & ,330 & ,868 \\
\hline Age & 021 &, 010 & 4,699 & 1 &, 030 & 1.021 & 1,002 & 1,040 \\
\hline Time housing &,- 145 & 077 & 3,582 & 1 & 058 &, 865 &, 744 & 1,005 \\
\hline Onion Producers &,- 409 & 243 & 2,833 & 1 & 092 & 1,505 & ,935 & 2,421 \\
\hline Use of agro-chemicals & 1,164 & 419 & 7,726 & 1 & ,005 & 3,203 & 1,410 & 7,279 \\
\hline Family intoxication & 1,111 & 302 & 13,492 & 1 &, 000 & 3,038 & 1,679 & $\overline{5,496}$ \\
\hline Hours worked / harvesting &,- 215 & 061 & 12,450 & 1 &, 000 & ,807 & ,716 & ,909 \\
\hline $\begin{array}{l}\text { Hours worked / outside } \\
\text { harvesting }\end{array}$ & ,287 & ,085 & 11,453 & 1 & ,001 & 1,322 & 1,128 & 1,573 \\
\hline
\end{tabular}

Regarding sociodemographic characteristics and working process, mental health problems predictive variables were male sex (smaller chances than females), age (higher chances with age), use of agrochemicals, working hours outside harvesting and during harvesting, but the most important variable was intoxication in the family.

\section{Discussion}

Family farmers workers presented a mean age (48.95 years) considered as high when compared to other professional fields. This ageing tendency of the farming population was verified during the studies done by Lima et al. (2009) and Faria et al. (2000). Education level is low, as evidenced in other studies developed in Brazil (Faria et al., 2000). This situation is different when compared to American farmers, which usually have high school level (Alavanja et al. 1996).

Regarding the family agricultural working process, studied properties present a mean area of 17 ha, a similar average to family properties in Brazil, which are 18 ha (IBGE, 2007). Mean working hours are extensive, especially for farmers cultivating tobacco. During harvesting, the average working schedule is increased by three hours, reaching over 16 hours of work. Gregoire (2002), in the United Kingdom, observed long working hours $(70 \%$ work over 10 hours per day).

A high prevalence $(33.8 \%)$ of mental health problems was detected, like in other family farmers at Serra Gaucha - Rio Grande do Sul Highlands (Faria et al., 2000), in Nicaragua (Penayo et al., 1990) and in Africa (Rumble et al., 1996).

However, in first world countries, given better agricultural conditions, a smaller prevalence of mental health problems is noticed (Robins et al., 1984; Lewis; Booth, 1994). In third world countries, prevalence is higher (Cheng, 1988; Hwu; Yeh; Chang, 1989; Lee et al., 1990).

It was observed that mental health problems are more prevalent in women and become worse with older age, both for men and women, especially after their 40's. Women have an intense working schedule, as besides working in the farm, they are also responsible for house chores, children and family.

Use of machinery and equipment in the property, an indicator of technological development, and hiring of staff were associated to less prevalence of mental health problems. 
The use of pesticides is intense in both onion and tobacco crops and is present in $85.9 \%$ of studied properties. Farmers stated feeling sick during the manipulation of pesticides and the majority say that they do not usually wear individual protection equipment. It was observed that $40.5 \%$ affirmed having intoxication problems in the family and $23.7 \%$ affirmed that they were intoxicated themselves. Women present higher prevalence of mental health problems, both that had intoxication in the family and that were intoxicated themselves; the higher number was with women that were intoxicated.

Both use of pesticides without proper protection and intoxications showed being directly related to mental health problems of family farmers under study. The problem of agro-chemicals use has been discussed in studies (Montedo, 2001; Monteiro, 2004) and it was noticed that farmers do not protect themselves when applying them, which could endanger their health.

The high prevalence of mental health problems was verified in this research and associations were shown to the use of pesticides. Studies by Stallones et al. (1995) and Faria et al. (1999) show that depression is pathology closely linked to the contact of pesticides, however without a single cause. During the study it was verified that a large quantity of agro-chemicals was used in the tobacco and onion crops, and further studies are needed to investigate the risks to which these farmers are exposed.

\section{Conclusions}

The use of SRQ 20 revealed that family agricultural workers have a high risk of mental health problems. Variables identified as predictors of mental health problems are: sex, age, time of living in the area, working hours (harvesting and outside harvesting) and the use of agro-chemicals. The study identifies as the most important variable family intoxication, a relevant fact for occupational health.

Results show the need for a set of measures to minimize the harming effects on the mental health of family agricultural workers, in the sense of developing proper care services for this population. There is a lack of a specific mental health service model for the farming community, as farmers represent a vulnerable population group in terms of attention given to occupational health problems and needs. Diseases caused by agro-chemicals represent a serious public health problem and show the complexity of being exposed to agro-chemicals at work and the importance of researches that aim in changing work in order that contact with dangerous substances is avoided.

Based upon these results, information is available to the epidemiology, sanitary, agricultural services as well as other related organs for the development of occupation health prevention policies for family farming workers, especially regarding mental health problems and intoxication issued in the researched area and in the implementation of programs at Federal and State levels. Therefore, new studies are proposed to further investigate these themes, in view a better understanding about the complexity of family agricultural work and problems to both physical and mental health.

\section{References}

[1] Alavanja, M.C.R., et al. The agricultural health study. Environmental Health Perspectives, v. 104, p. 362-369, 1996.

[2] Barbeta, P. A. Estatística aplicada às Ciências Sociais. 5.ed. Florianópolis: Editora da UFSC, 2003.

[3] Booth, N.; Lloyd, K. Stress in farmers. International Journal of Social Psychiatry, v. 46, n. 1, p. 67-73, 1999.

[4] Booth, N.; Briscoe, M.; Powell, R. Suicide in the farming community: Methods used and contact with health services. Occupational and Environmental Medicine, v. 57, p. 642$645,2000$.

[5] Cheng, T. A. A community study of minor psychiatric morbiity in Taiwan. Psychological Medicine, v. 18, p. 953968, 1988.
[6] Conger, R. D. Suicide and rural economic problems Archives of General Psychiatry, v. 56, n. 12, p.110-118, 1999.

[7] Eisner, C. S.; Neal, R. D.; Scaife, B. The effect of the 1996 "beef crisis" on depression and anxiety in farmers and nonfarming controls. British Journal of General Practice, 49, p. 385-386, 1999.

[8] Falk, J. W.; Carvalho, L. A.; Silva, L. R.; Pinheiro, S. Suicídio e Doença Mental em Venâncio Aires-RS: Consequêencia do Uso de Agrotóxicos Organofosforados. Relatório Preliminar de Pesquisa, n. 1-4, p. 23- 31, 2003.

[9] Faria, N. M. X.; Facchini, L. A.; Fassa, A. G.; Tomasi, E. Estudo transversal sobre saúde mental de agricultores da 
Serra Gaúcha (Brasil). Revista de Saúde Pública, São Paulo, v. 33, n. 4, p. 391-400, 1999

[10] Faria N. M. X.; Facchini, L. A.; Fassa, A. G.; Tomasi, E. O processo de produção rural na serra gaúcha: Um estudo descritivo. Caderno de Saúde Pública, Rio de Janeiro, v. 16, n.1, p.11-128, 2000.

[11]Fragar, L.; Franklin, R. The health and safety of Australia's farming community. ACAHS e RIRDC: Moree, 2000

[12] Gregoire. A. The mental health of farmers. Occupational Medicine, 58 (8), pp. 471-476, 2002.

[13] Harding, T. W. et al. Mental Disorders in primary health care: a study of their frequency and diagnosis in four development countries. Psychological Medicine, v.10, pp. 231-241, 1980

[14]Hwu, H.G.; Yeh, E.K.; Chang, L.Y. Prevalence of psychiatric disorders in Taiwan defined by Chinese diagnostic interview schedule. Acta Psychiatrica Scandinavica, v. 79, pp.136-147, 1989.

[15]IBGE. Censo Agropecuário 2006: Resultados preliminares. Rio de Janeiro: IBGE, 2007, $141 \mathrm{p}$

[16]Lewis, G.; Booth, M. Are cities bad for your mental health? Psychological Medicine, v. 24, p. 913-968, 1994.

[17]Lima, C. A. B.; et al. Diagnóstico da exposição ocupacional a agrotóxicos na principal região produtora de pêssego para indústria do Brasil. Ciência Rural, Santa Maria, v. 39, n. 3, 2009.

[18]Lobley, M. et al. Rural stress review. Centre for Rural Research, Lafrowda House, University of Exeter. St German's Road: Exeter, 2004.

[19] Malmberg, A.; Hawton, K.; Simkin, S. A study of suicide in farmers in England and Wales. Journal of Psychosomatic Research, 43 (1), p. 107-111, 1997.

[20] Mari, J.; Williams P. A. A validity study of a psychiatric screening questionnaire (SRQ-20) in primary care in the city of São Paulo. British Journal Psychiatry, v. 148, p. 23-26, 1986.

[21]Mari, J. et al. Detection of psychiatric morbidity in the primary medical care settings in Brazil. Revista de Saúde Pública, v.21, p. 501-507, 1987.

[22] McGregor, M.; Willock, J.; Deary, I. Farmer Stress. Farm Management, v. 9, p.57-65, 1995.
[23] Montedo, U. B. O trabalho agrícola familiar segundo a teoria da complexidade. 2001, 289f. Tese (Doutorado em Engenharia de Produção). Programa de Pós-Graduação em Engenharia de Produção, Universidade Federal de Santa Catarina. Florianópolis, 2001.

[24] Monteiro, J. O processo de trabalho e o desencadeamento dos agravos à saúde do trabalhador: um estudo ergonômico na agricultura familiar de Santa Catarina. 2004. 182f. Tese (Doutorado em Engenharia de Produção). Programa de PósGraduação em Engenharia de Produção, Universidade Federal de Santa Catarina. Florianópolis, 2004.

[25] Penayo, U; Kullgren, G; Caldera, T. Mental disorders among primary health care patients in Nicaragua. Acta Psychiatrica Scandinavica, p, 82-85, 1990.

[26] Pickett, W. et al. 1998. Suicide mortality and pesticide use among Canadian farmers. American Journal Industrial Medicine, v. 16 (1), p. 115-128, 1998.

[27]Robins, I. N. et al. Lifetime prevalence of specific psychiatric disorders in three sites. Archives of General Psychiatric, v.41, p. 949-958, 1984.

[28] Rumble, S. et al. Prevalence of psychiatric morbidity in the adult population of a rural South African village. Psychological Medicine, v. 26, p. 997-1007, 1996.

[29] Stallones, L. et al. Depressive symptoms among Colorado farmers. Agricultural Safety and Health, v. 1, p. 37-43, 1995.

[30] Wilkinson, R. Health inequalities: relative or absolute material standards? BMJ, v. 314, p. 581-585, 1987. 